\title{
Protótipo de Habitação de interesse social autoconstruída segundo princípios da produção mais limpa.
}

\section{Erica de Matos Miranda*, Eloisa Dezen Kempter.}

\section{Resumo}

Neste projeto foram realizados estudos e pesquisas sobre o tema Habitação de Interesse Social (HIS) e Produção mais Limpa $(\mathrm{P}+\mathrm{L})$ no bairro Geada em Limeira-SP. Foi aplicada uma Pesquisa de Preferência Declarada visando obter informações sobre conceitos de valor e melhorias no ambiente habitacional e assim propor alterações no projeto arquitetônico visando flexibilizar o projeto padrão para adequá-lo às necessidades da diversidade populacional.

Palavras-chave: conceitos de valor, ambiente habitacional, produção mais limpa.

\section{Introdução}

Este projeto pretende aliar dois temas de relevância: habitação de interesse social e sustentabilidade na construção civil. Portanto tem como alvo principal prestar suporte técnico, aos moradores do Programa Minha Casa Minha Vida (PMCMV) no processo de adequação da moradia entregue, empregando práticas de produção mais limpa $(\mathrm{P}+\mathrm{L})$, reduzindo impactos ambientais e o custo da obra.

Foi aplicada uma Pesquisa de Preferência Declarada através de cartas ilustradas e entrevistas semiestruturadas. Assim, o respondente tinha condição de hierarquizar as alternativas à sua disposição, favorecendo as pesquisas. Com isso foram obtidos resultados sobre as satisfações dos indivíduos com seu ambiente habitacional e características das moradias.

\section{Resultados e Discussão}

Com base nos resultados da pesquisa aplicada no Empreendimento do PMCMV no bairro Geada, podese observar a variedade de grupos familiares residentes no bairro como mostra a figura 1.

Figura 1. Grupos Familiares.

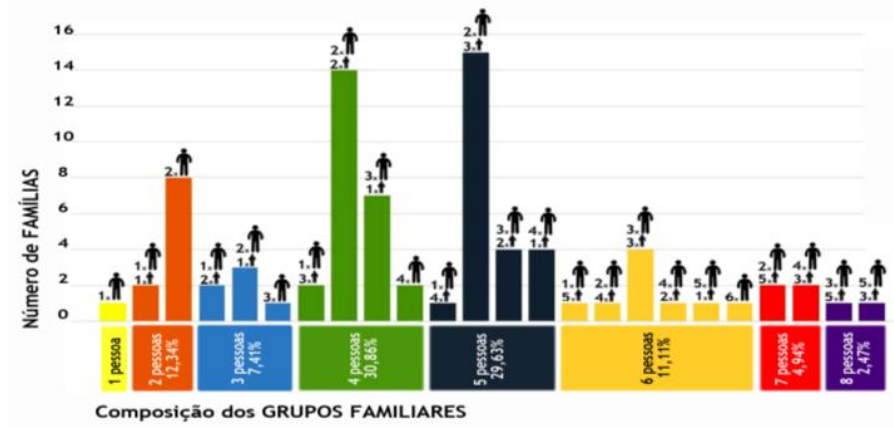

Podemos observar na Fig. 1 que 0 bairro apresenta famílias de até 8 pessoas, sendo que a maioria dos grupos familiares são compostos de 4 a 5 membros A pesquisa de PD revelou que os moradores mesmo satisfeitos com a moradia entregue pretendiam fazer modificações, para adequar o produto entregue às condições da composição familiar.
Para que a casa pudesse ser ajustada aos diversos grupos familiares, foram comparados custos da moradia entregue com uma proposta de casa com ambientes de permanência prolongada flexibilizados, e cuja separação empregaria o princípio de $\mathrm{P}+\mathrm{L}$.

Figura 2. Unidade Padrão do PMCMV (esq.) e Unidade proposta (dir).

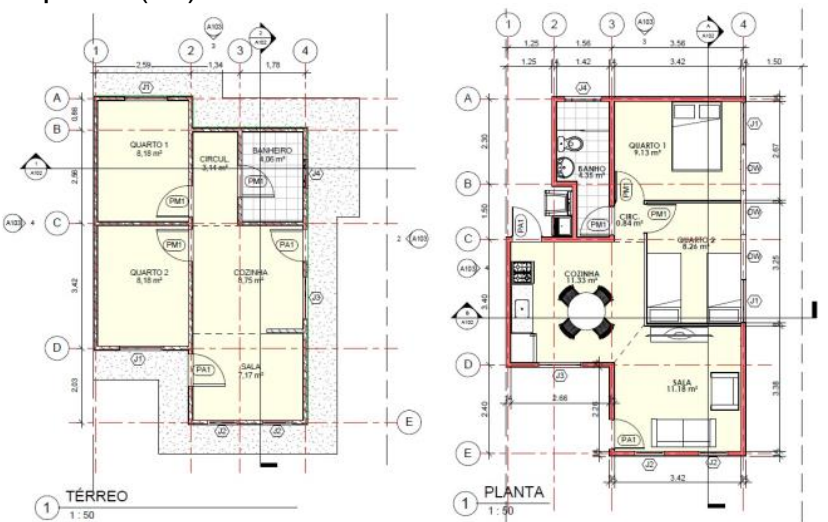

O modelo de casa proposto possui paredes internas de gesso acartonado, separando a sala dos dormitórios, possibilitando adequações às especifidades de cada família.

\section{Conclusões}

A partir dos dados da pesquisa de campo, aferidos estatisticamente, ficou clara a percepção dos moradores e suas necessidades espaciais em função da diversidade dos grupos familiares que o PMCMV contempla.

Conclui-se que os custos de uma unidade que oferece pouca flexibilidade de adaptação, devido ao sistema construtivo empregado, com a proposta que possibilita grande adaptabilidade estão muito próximos, o que justifica uma reflexão, por parte dos gestores, do que está sendo oferecido para a população.

\section{Agradecimentos}

Agradeço à orientadora Eloisa Dezen-Kempter por todo auxílio e suporte durante a pesquisa, aos moradores do Bairro Geada pela colaboração e aos alunos e pesquisadores da FT da Unicamp que me auxiliaram quando necessário durante o processo. 